\title{
Alternative finishing strategies for Holstein-Friesian bulls slaughtered at 15 months of age
}

\author{
Brian Murphy ${ }^{1,2,3}$, Alan K. Kelly ${ }^{2}$ and Robert Prendiville ${ }^{1}$ \\ ${ }^{1}$ Animal Grassland Research and Innovation Centre, Teagasc, Grange, Dunsany, Co. Meath, Ireland; \\ ${ }^{2}$ School of Agriculture and Food Science, University College Dublin, Belfield, Dublin 4, Ireland; \\ ${ }^{3}$ Teagasc Environmental Research Centre, Johnstown Castle, Co. Wexford, Ireland. \\ e-mail: robert.prendiville@teagasc.ie
}

\begin{abstract}
The aim was to establish the optimum finishing strategy (FS) for dairy bulls slaughtered at 15 months. Sixty springborn calves were assigned to one of four FS. The FS were split into two phases; pasture (PAS) from mid-August to housing (P1) and finished indoors on concentrates ad libitum plus straw for $209 \mathrm{~d}$ (P2). Treatment 1 (T1) was offered PAS in P1 and $800 \mathrm{~g} \mathrm{~kg}^{-1}$ barley (BAR), $140 \mathrm{~g} \mathrm{~kg}^{-1}$ soya bean meal (SBM), $40 \mathrm{~g} \mathrm{~kg}^{-1}$ molasses and $20 \mathrm{~g} \mathrm{~kg}^{-1}$ minerals (B) in P2. Treatments 2 (T2) and 3 (T3) were offered $3 \mathrm{~kg}$ dry matter (DM) of B per head daily at PAS. In P2, T2 was offered $B$ while T3 was offered $400 \mathrm{~g} \mathrm{~kg}^{-1} \mathrm{BAR}, 400 \mathrm{~g} \mathrm{~kg}^{-1}$ maize meal, $140 \mathrm{~g} \mathrm{~kg}^{-1} \mathrm{SBM}, 40 \mathrm{~g} \mathrm{~kg}^{-1}$ molasses and $20 \mathrm{~g} \mathrm{~kg}^{-1}$ minerals (BM). In P1 treatment 4 (T4) was offered $3 \mathrm{~kg}$ DM of BM per head daily at PAS and $750 \mathrm{~g} \mathrm{~kg}^{-1} \mathrm{BAR}, 140 \mathrm{~g} \mathrm{~kg}^{-1}$ $\mathrm{SBM}, 50 \mathrm{~g} \mathrm{~kg}^{-1}$ rumen protected fat, $40 \mathrm{~g} \mathrm{~kg}^{-1}$ molasses and $20 \mathrm{~g} \mathrm{~kg}^{-1}$ minerals in P2. Finishing strategy did not affect lifetime average daily gain or carcass conformation. Fat score tended $(p=0.0514)$ to be greater for T3 than T1 and T4.
\end{abstract}

Key words: young bull, pasture, carcass weight, fat score

\section{Introduction}

Bull beef production systems have the potential to increase carcass output per hectare by slaughtering animals at a younger age and produce less greenhouse gas (GHG) emissions than steer beef systems (Nogalski et al. 2014, Murphy et al. 2017a). Currently, 13\% of male animals are slaughtered as bulls in Ireland (Bord Bia 2016). Animals slaughtered at a younger age require concentrate intensive finishing diets to ensure an acceptable carcass at slaughter (O'Riordan et al. 2012). Although integrating a greater proportion of grazed grass in the diet reduced feed costs (Ashfield et al. 2014), intensive young bull production systems require high levels of concentrates to ensure optimum animal performance throughout the animal's lifetime.

Growth rate is a key driver of biological efficiency and profit in bull beef systems (Pettigrew et al. 2017). Male dairy calves managed in young bull systems in the UK are typically housed indoors on a concentrate intensive diet where little/no grazed grass is incorporated into the feed budget (Meat Promotion Wales 2014). In contrast, moderate levels of performance are common for male dairy calves at pasture during the first grazing season in Ireland which is attributed to the blueprint for the traditional 24 month steer production system (Keane and Allen 1998). Although such performance levels during the weaned calfhood stage are appropriate for steer systems, greater levels of performance are required throughout the animals' lifetime for young bull beef systems. When grazed pasture is incorporated into the diet during the first grazing season methods of increasing the nutritive value of the feed available to weaned calves assigned to young bull beef systems during summer and autumn is necessary to optimise performance (Pettigrew et al. 2017). Indeed, Pettigrew et al. (2017) reported that bulls grazing herb sward had superior growth rates than bulls grazing pasture and pasture supplemented with concentrates. Murphy et al. (2017b) also reported greater average daily gains (ADG), heavier calf housing weights and greater fat scores at slaughter for spring born male dairy calves offered greater levels of concentrate supplementation during the first season at pasture. However, Murphy et al. (2017b) also demonstrated that dairy bulls slaughtered at 15 months of age on a concentrate intensive finishing diet had inadequate carcass weight and fat score and concluded that greater levels of concentrate should be supplemented at pasture before housing or the finishing period should be greater than 200 days.

Carcass fat score is an integral component of carcass value (Bown et al. 2016) and Ladeira et al. (2016) stated that genetic factors, age at slaughter, growth rate and gender are parameters that influence the amount and composition of fat. Since young bulls are more efficient at converting nutrients to muscle than steers (Steen 1995) achieving the minimum requirement for fat score for bulls slaughtered at a younger age can be a challenge. However, De Smet et al. (2000) reported that increasing the energy density in the finishing diet increased carcass fat. 
Similarly, More O'Ferrall et al. (1989) showed that as the energy density of the diet increased, ADG, conformation score and kill-out proportion also increased while age at slaughter decreased. One avenue to increase the energy density of the finishing diet is by way of supplementation with energy dense ingredients such as maize and rumen protected fat (More O'Ferrall and Keane 1989, Nürnberg et al. 1998). Therefore the objective of this study was to establish the optimum finishing strategy for male dairy calves slaughtered at 15 months of age combining alternative supplementation strategies at pasture and energy density of the finishing ration.

\section{Materials and methods}

\section{Animals and treatments}

This study was conducted at the Teagasc Johnstown Castle Research Centre $\left(52^{\circ} 17^{\prime} \mathrm{N}, 6^{\circ} 30^{\prime} \mathrm{W}\right)$ from February 2014 to June 2015. Sixty spring-born male Holstein-Friesian (HF) calves were purchased from commercial dairy farms and livestock marts and artificially reared on site similar to that described by Fallon (1992). Calves were generated from 23 artificial insemination (AI) bulls commonly available in Ireland and 4 stock bulls (sired 1 calf each) while 12 calves had an unrecorded HF sire. Mean date of birth and arrival age were 6 February 2014 and 23 (SD 6.6) days, respectively. Calves were turned out to pasture on 24 April and offered $1 \mathrm{~kg}$ dry matter (DM) per head daily of a calf ration (350 g kg-1 barley; $140 \mathrm{~g} \mathrm{~kg}^{-1}$ soya hulls; $120 \mathrm{~g} \mathrm{~kg}^{-1}$ soya; $100 \mathrm{~g} \mathrm{~kg}^{-1}$ rapeseed meal; $90 \mathrm{~g} \mathrm{~kg}^{-1}$ molasses; $80 \mathrm{~g} \mathrm{~kg}^{-1}$ flaked maize; $50 \mathrm{~g} \mathrm{~kg}^{-1}$ wheat distillers; $50 \mathrm{~g} \mathrm{~kg}^{-1}$ beef pulp and $20 \mathrm{~g} \mathrm{~kg}^{-1}$ minerals). Calves were rotationally grazed on a paddock system. Ivomec $1 \%$ injection (Merial Limited, Georgia, USA) was administered at 4, 8 and 12 weeks post-turnout to control internal parasites. On 12 August calves were randomly assigned to one of four finishing strategies blocked by date of birth, farm of origin and live weight. Live weight on 12 August and ADG from weaning to assignment of treatment were 177 (SD 22.3) kg and 0.84 (SD 0.143 ) kg, respectively.

The experimental overview is presented in Figure 1. The finishing regime comprised of alternative supplementation strategies at pasture (from 12 August to 3 November; P1) and contrasting energy density rations offered during the finishing period (P2). The finishing strategies included a pasture only diet in P1 followed by $800 \mathrm{~g} \mathrm{~kg}^{-1}$ barley, $140 \mathrm{~g} \mathrm{~kg}^{-1}$ soya bean meal, $40 \mathrm{~g} \mathrm{~kg}^{-1}$ molasses and $20 \mathrm{~g} \mathrm{~kg}^{-1}$ minerals (B) in P2 (T1), pasture plus $3 \mathrm{~kg}$ DM of $\mathrm{B}$ per head daily in P1 followed by B in P2 (T2), pasture plus $3 \mathrm{~kg}$ DM of B per head daily in P1 followed by $400 \mathrm{~g}$ $\mathrm{kg}^{-1}$ barley, $400 \mathrm{~g} \mathrm{~kg}^{-1}$ maize meal, $140 \mathrm{~g} \mathrm{~kg}^{-1}$ soya bean meal, $40 \mathrm{~g} \mathrm{~kg}^{-1}$ molasses and $20 \mathrm{~g} \mathrm{~kg}^{-1} \mathrm{minerals}$ (BM) in P2 (T3) or pasture plus $3 \mathrm{~kg}$ DM of BM per head daily in P1 followed by $750 \mathrm{~g} \mathrm{~kg}^{-1}$ barley, $140 \mathrm{~g} \mathrm{~kg}^{-1}$ soya bean meal, $50 \mathrm{~g} \mathrm{~kg}^{-1}$ rumen protected fat (Megalac ${ }^{\circledR}$, Volac International Limited, UK), $40 \mathrm{~g} \mathrm{~kg}^{-1}$ molasses and $20 \mathrm{~g} \mathrm{~kg}^{-1} \mathrm{miner}^{-}$ als (BRPF) in P2 (T4).

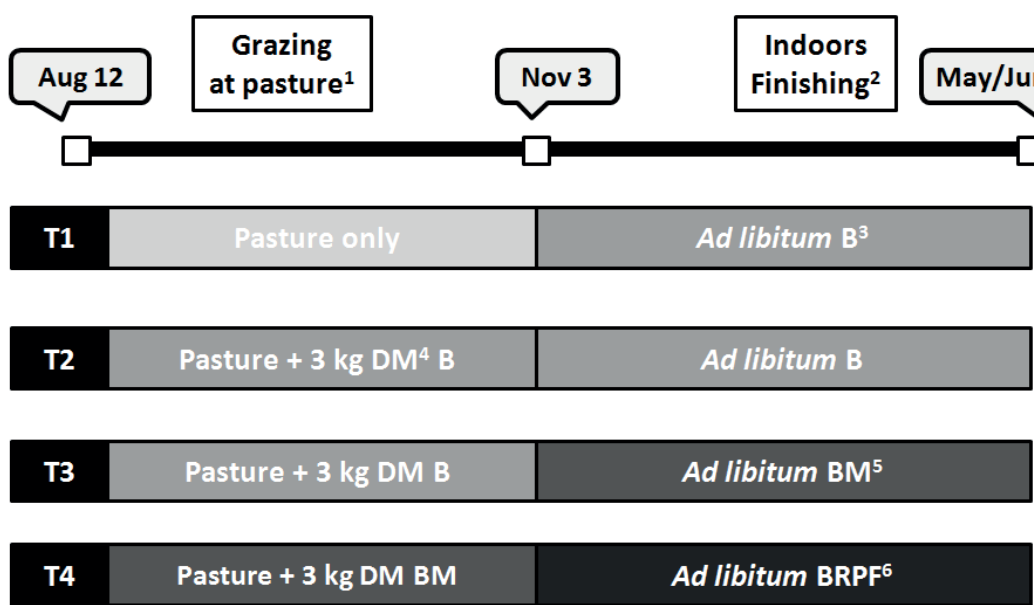

Fig. 1 Experimental overview of the treatments imposed in the study. ${ }^{1}$ rotationally grazed at pasture from 12 August to housing on 3 November; ${ }^{2}$ housed indoors on a slatted floor accommodation and offered a concentrate ad libitum diet from housing to slaughter; ${ }^{3} 800 \mathrm{~g}$ $\mathrm{kg}^{-1}$ barley, $140 \mathrm{~g} \mathrm{~kg}^{-1}$ soya bean meal, $40 \mathrm{~g} \mathrm{~kg}^{-1}$ molasses and $20 \mathrm{~g} \mathrm{~kg}^{-1}$ minerals; ${ }^{4}$ dry matter; ${ }^{5} 400 \mathrm{~g} \mathrm{~kg}^{-1}$ barley, $400 \mathrm{~g} \mathrm{~kg}^{-1}$ maize meal, $140 \mathrm{~g} \mathrm{~kg}^{-1}$ soya bean meal, $40 \mathrm{~g} \mathrm{~kg}^{-1}$ molasses and $20 \mathrm{~g} \mathrm{~kg}^{-1}$ minerals; ${ }^{6} 750 \mathrm{~g} \mathrm{~kg}^{-1}$ barley, $140 \mathrm{~g} \mathrm{~kg}^{-1}$ soya bean meal, $50 \mathrm{~g} \mathrm{~kg}^{-1}$ rumen protected fat (Megalac ${ }^{\circledR}$, Volac International Limited, UK), $40 \mathrm{~g} \mathrm{~kg}^{-1}$ molasses and $20 \mathrm{~g} \mathrm{~kg}^{-1}$ minerals. 


\section{Sward management and dietary analysis}

In P1 pre- and post-grazing sward heights were measured using a rising plate meter (Jenquip, New Zealand). Pregrazing herbage yields were determined on each paddock by cutting 4 quadrats $(0.5 \mathrm{~m} \times 0.5 \mathrm{~m})$ representative of the herbage available, using an electric shears (Accu Grass Shears Comfortcut, Gardena Ltd, Germany) as described by O'Donovan et al. (2002). Herbage yield and pre- and post-grazing swards heights were used to estimate individual grass DM intake (GDMI). Pasture samples were collected weekly throughout P1, while concentrate samples were collected weekly throughout P1 and P2. Samples were duplicated. The first sample was oven dried at $100{ }^{\circ} \mathrm{C}$ for 24 hours for DM determination and discarded. The second sample was oven dried at $40{ }^{\circ} \mathrm{C}$ for 48 hours to determine the chemical composition. These samples were then milled through a $1 \mathrm{~mm}$ metal sieve (C \& M Junior Laboratory Mill). Pasture and concentrate samples were pooled on a fortnightly basis. All samples were analysed for neutral detergent fibre (NDF), using the Ankom method (F57 Ankom Technology, Macedon, NY). The remainder of the analysis was as described by Owens et al. (2008). Pasture samples were analysed in vitro for DM and organic matter digestibility, crude ash, crude protein and water soluble carbohydrates. Concentrate samples were also analysed for starch, crude ash and crude protein. Chemical composition of the pasture and concentrates offered during the experimental period are presented in Table 1. Net energy values for grazed pasture and concentrate diets (Unit Fourragere Viande [UFV]) were estimated using the French NE system (INRA 1989) as modified by O’Mara (1996) for Irish conditions.

Table 1. Chemical composition of the feed offered during the experimental period

\begin{tabular}{|c|c|c|c|c|}
\hline & Pasture $^{1}$ & $\mathrm{~B}^{2}$ & $\mathrm{BM}^{3}$ & $\mathrm{BRPF}^{4}$ \\
\hline Dry matter (DM: $\mathrm{g} \mathrm{kg}^{-1}$ ) & $\begin{array}{c}156 \\
\left(S^{5} 4.3\right)\end{array}$ & $\begin{array}{c}848 \\
\text { (SD 1.0) }\end{array}$ & $\begin{array}{c}847 \\
(S D 1.0)\end{array}$ & $\begin{array}{c}850 \\
(S D 0.9)\end{array}$ \\
\hline Crude ash (g kg DM-1) & $\begin{array}{c}95.8 \\
\text { (SD 14.87) }\end{array}$ & $\begin{array}{c}63.3 \\
(S D 10.98)\end{array}$ & $\begin{array}{c}68.9 \\
(S D 11.51)\end{array}$ & $\begin{array}{c}81.3 \\
(S D 7.83)\end{array}$ \\
\hline Crude protein ( $\mathrm{g} \mathrm{kg} \mathrm{DM}^{-1}$ ) & $\begin{array}{c}233.9 \\
\text { (SD } 38.43)\end{array}$ & $\begin{array}{c}169.8 \\
(S D 12.08)\end{array}$ & $\begin{array}{c}156.5 \\
(S D 9.10)\end{array}$ & $\begin{array}{c}182.1 \\
(S D 16.64)\end{array}$ \\
\hline Starch (g kg DM $\left.{ }^{-1}\right)$ & - & $\begin{array}{c}436.1 \\
(S D 24.92)\end{array}$ & $\begin{array}{c}468.8 \\
\text { (SD 14.08) }\end{array}$ & $\begin{array}{c}401.9 \\
(S D 50.80)\end{array}$ \\
\hline Neutral detergent fibre (g kg DM ${ }^{-1}$ ) & $\begin{array}{c}487.6 \\
\text { (SD 42.25) }\end{array}$ & $\begin{array}{c}148.4 \\
(S D 17.71)\end{array}$ & $\begin{array}{c}120.9 \\
(S D 3.68)\end{array}$ & $\begin{array}{c}134.3 \\
(S D 6.17)\end{array}$ \\
\hline DM digestibility (g kg DM-1) & $\begin{array}{c}758.4 \\
\text { (SD } 30.76)\end{array}$ & - & - & - \\
\hline Organic matter digestibility $\left(\mathrm{g} \mathrm{kg}^{-1}\right.$ ) & $\begin{array}{c}749.4 \\
\text { (SD 32.69) }\end{array}$ & - & - & - \\
\hline $\begin{array}{l}\text { Water soluble carbohydrates } \\
\left(\mathrm{g} \mathrm{kg} \mathrm{DM}^{-1}\right)\end{array}$ & $\begin{array}{c}124.9 \\
\text { (SD 62.19) }\end{array}$ & - & - & - \\
\hline Unité Fourragère Viande (UFV; kg-1) & 0.92 & 0.96 & 0.98 & 1.03 \\
\hline
\end{tabular}

${ }^{1}$ Chemical composition of the pasture quality offered to treatment groups from 12 August to 3 November; ${ }^{2} \mathrm{~B}$ consisted of $800 \mathrm{~g} \mathrm{~kg}^{-1}$ barley, $140 \mathrm{~g} \mathrm{~kg}^{-1}$ soya bean meal, $40 \mathrm{~g} \mathrm{~kg}^{-1}$ molasses and $20 \mathrm{~g} \mathrm{~kg}^{-1} \mathrm{minerals}^{3}{ }^{3} \mathrm{BM}$ consisted of $400 \mathrm{~g} \mathrm{~kg}^{-1}$ barley, $400 \mathrm{~g} \mathrm{~kg}^{-1}$ maize meal, $140 \mathrm{~g} \mathrm{~kg}^{-1}$ soya bean meal, $40 \mathrm{~g} \mathrm{~kg}^{-1}$ molasses and $20 \mathrm{~g} \mathrm{~kg}^{-1}$ minerals; ${ }^{4} \mathrm{BRPF}$ consisted of $750 \mathrm{~g} \mathrm{~kg}^{-1}$ barley, $140 \mathrm{~g} \mathrm{~kg}^{-1}$ soya bean meal, $50 \mathrm{~g} \mathrm{~kg}^{-1}$ megalac ${ }^{\circledast}, 40 \mathrm{~g} \mathrm{~kg}^{-1} \mathrm{molasses}$ and $20 \mathrm{~g}$ $\mathrm{kg}^{-1}$ minerals; ${ }^{5}$ Standard deviation of the mean

\section{Animal management}

Calves were vaccinated against Infectious Bovine Rhinotracheitis (Rispoval IBR Marker-Live, Pfizer Animal Health, Cork, Ireland), Bovine Respiratory Syncytial Virus, Pasturella, Parainfluenza-3 virus (Bovipast RSP, Intervet, Schering-Plough Ltd., Wicklow, Ireland) and clostridial diseases (Covexin10, Schering-Plough Ltd.). Calves were housed on 3 November on a slatted floor accommodation and immediately adapted to a concentrate ad libitum diet over a 21 day period. Two weeks post-housing, Closamectin pour-on (Norbrook Laboratories Ltd.) was applied on the bulls. Bulls were divided into 3 pens ( 3.4 by 5 meters) within treatment, with 5 bulls per pen during the finishing period. Fresh concentrates were weighed into each pen daily and refusals were weighed back twice weekly.

Straw was available on an ad libitum basis to maintain normal rumen function. Clean fresh water was available. Bulls were finished over a 209 (SD 8.5) day period and slaughtered at 478 (SD 6.6) days of age. Bulls were selected for slaughter on three different sale dates based on the date of birth on their animal passport to ensure that they were 15 months of age at slaughter. 
Bulls were weighed fortnightly throughout the experiment using a 'Weigh Crate' (O'Donovan's Engineering, Cork, Ireland) and the 'Winweigh' software package (Tru-test Ltd., Auckland, New Zealand). Average daily gain during the pre-experimental period (24 April to 11 August), P1 and P2 were calculated using linear regression of live weight against recording date for each bull. Bulls were weighed at housing and again 4 days later in an attempt to correct for the variation caused by gut-fill. On the morning of slaughter, bulls were transported $63 \mathrm{~km}$ to a commercial slaughter plant and weighed in the lairage approximately 1 hour pre-slaughter using a portable 'Platform Weigher' (O’Donovan's Engineering, Cork, Ireland).

\section{Ultrasonic and live animal measurements}

Ultrasonic muscle and subcutaneous fat depth were recorded on the right hand side of each carcass using a Dynamic Imaging Ultrasound Scanner (Concept IMCV with 3.5 MHZ head) at 18 (SD 8.5) and 79 (SD 8.5) days preslaughter. Subcutaneous fat depth was calculated as the mean of four points on the rump, four points at the $13^{\text {th }}$ rib and three points at the third lumbar. Longissimus dorsi muscle depth was measured at the $3^{\text {rd }}$ lumbar from the top of the bone to the bottom of the back fat layer. Simultaneously, live animal measurements were recorded and expressed as a proportion of live weight (De Boer et al. 1974). Chest depth and pelvic width were measured using a callipers (Mantax Black Callipers, Haglof, Sweden), while height at withers, chest circumference and length of back were recorded using a fibreglass measuring tape.

\section{Carcass assessment}

Post-slaughter carcass weight was determined for each bull (hot carcass weight $\times 0.98$ ). Perinephric and retroperitoneal fat was weighed and recorded from both sides of each carcass. Video imaging analysis carcass classification system (VBS 2000, E+V, Germany) mechanically assigned each carcass side a carcass conformation and fat score on a 15 point scale using the EU Beef Carcass Classifications Scheme (EC 2006). Carcass measurements were recorded on the right hand side of each carcass as described by De Boer et al. (1974). Carcasses were hung from the Achilles tendon and stored at $4{ }^{\circ} \mathrm{C}$. After 48 hours carcasses were divided into fore and hind quarters. Ultimate $\mathrm{pH}$ and temperature were recorded at the $10^{\text {th }}$ rib from the $M$. longissimus thoracic prior to deboning using a combined $\mathrm{pH}$ and temperature meter (Hanna Model HI 9125, Hanna Instruments, Bedfordshire, UK) and a penetration glass $\mathrm{pH}$ probe (Hanna Model FC231D, Hanna Instruments, Bedfordshire, UK). The $5^{\text {th }}$ to $10^{\text {th }}$ rib joint was removed from the right hand side of each carcass. The area of the $M$. longissimus was traced at the $10^{\text {th }}$ rib and the area was determined using the Java image processing programme (Schneider et al. 2012). The rib joint was separated into muscle (M. longissimus plus other muscle) and bone (including ligamentum nuchae).

\section{Statistical analysis}

The PROC UNIVARIATE procedure of SAS (Statistical Analysis System, version 9.3; SAS Institute Inc., Cary, NC, USA, 2011) was used to test the normality of data distribution. Animal was the experimental unit for all variables, with the exception of feed intake and efficiency where pen was the experimental unit. Data were analysed using a randomised mixed model analysis of variance with the PROC MIXED procedure of SAS. Finishing strategy was included as fixed effect in the model. Least square means and standard error of the mean were used to discern the differences between treatment means and to interpret the results.

\section{Results}

\section{Estimated individual DM intakes}

The quantity of pasture offered was similar for all treatment groups (Table 2). During the finishing period, concentrate DM intake (CDMI) was lowest for T3, greatest for T2 and intermediate for both T1 and T4 ( $p<0.01)$. Total CDMI (P1 and P2) was lowest for T1 and greatest for T2, both T3 and T4 were intermediate $(p<0.001)$.

\section{Animal and carcass performance}

Average daily gain during P1 (Table 3) was greatest for T4, lowest for T1 and intermediate for T2 and T3 $(p<0.05)$ but live weight at housing was similar for all treatment groups. During P2, ADG was similar for all treatment groups. Consequently, live weight at slaughter and carcass weight (Table 4) were similar irrespective of finishing strategy. Finishing strategy did not affect lifetime ADG, live weight per day of age or carcass weight per day of age. 
B. Murphy et al. (2018) 27: 28-37

Table 2. Effects of finishing regime on pre-and post-grazing sward heights and estimated individual dry matter intake (DMI) on Holstein-Friesian bulls slaughtered at 15 months of age

\begin{tabular}{|c|c|c|c|c|c|c|}
\hline & $\mathrm{T} 1^{1}$ & $\mathrm{~T} 2^{2}$ & $\mathrm{~T}^{3}$ & $\mathrm{~T}^{4}$ & SEM $^{5}$ & $p$ value \\
\hline \multicolumn{7}{|l|}{ Herbage: } \\
\hline Available herbage $\left(\mathrm{kg} \mathrm{DM} \mathrm{ha}^{-1}\right)$ & 1056 & 990 & 990 & 1075 & 145.0 & 0.9596 \\
\hline $\begin{array}{l}\text { Estimated individual GDMI } \\
\left(\mathrm{kg} \mathrm{DM}^{6} \text { head }^{-1}\right)\end{array}$ & 5.4 & 3.6 & 3.6 & 4.1 & 0.54 & 0.2108 \\
\hline \multicolumn{7}{|l|}{ Concentrates (kg DM head ${ }^{-1}$ ): } \\
\hline $\begin{array}{l}\text { Concentrate intake during the } \\
\text { first season at pasture }\end{array}$ & $0^{\mathrm{a}}$ & $212^{\mathrm{b}}$ & $212^{\mathrm{b}}$ & $211^{\mathrm{b}}$ & & $<0.001$ \\
\hline $\begin{array}{l}\text { Estimated individual concentrate } \\
\text { DMI during finishing }\end{array}$ & $1673^{\mathrm{ab}}$ & $1774^{b}$ & $1578^{a}$ & $1655^{\mathrm{ab}}$ & 34.8 & $<0.01$ \\
\hline Total concentrate DMI & $1673^{a}$ & $1986^{b}$ & $1790^{a c}$ & $1866^{\mathrm{bc}}$ & 34.8 & $<0.001$ \\
\hline \multicolumn{7}{|c|}{ 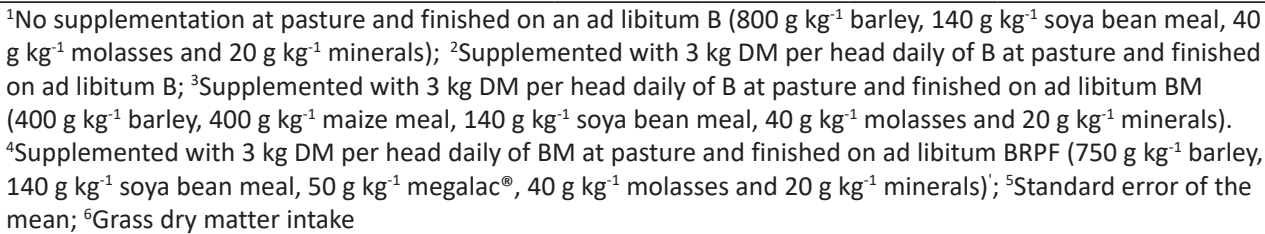 } \\
\hline
\end{tabular}

Table 3. Effects of finishing regime on the animal and carcass performance of Holstein-Friesian bulls slaughtered at 15 month of age

\begin{tabular}{|c|c|c|c|c|c|c|}
\hline & $\mathrm{T}^{1}{ }^{1}$ & $\mathrm{~T}^{2}$ & $\mathrm{~T}^{3}$ & $\mathrm{~T}^{4}$ & $\mathrm{SEM}^{5}$ & $p$ value \\
\hline Initial live weight (12 Aug; kg) & 175 & 181 & 173 & 181 & 6.1 & 0.7628 \\
\hline Live weight at housing (kg) & 247 & 256 & 263 & 270 & 7.9 & 0.2065 \\
\hline Live weight at slaughter (kg) & 546 & 572 & 554 & 552 & 15.0 & 0.5952 \\
\hline \multicolumn{7}{|l|}{ Average daily gains (ADG; kg): } \\
\hline ADG (August-November) & $0.90^{\mathrm{a}}$ & $0.96^{\mathrm{ab}}$ & $1.07^{\mathrm{ab}}$ & $1.10^{\mathrm{b}}$ & 0.047 & $<0.05$ \\
\hline ADG during finish & 1.56 & 1.55 & 1.47 & 1.40 & 0.052 & 0.1331 \\
\hline Lifetime ADG & 1.16 & 1.22 & 1.19 & 1.22 & 0.036 & 0.4925 \\
\hline Live weight per day of age & 1.14 & 1.20 & 1.16 & 1.15 & 0.031 & 0.5386 \\
\hline Carcass weight per day of age & 0.59 & 0.62 & 0.60 & 0.59 & 0.017 & 0.5181 \\
\hline \multicolumn{7}{|c|}{ Ultrasound and animal measurements (79 days pre slaughter): } \\
\hline Muscle depth (mm) & 57.3 & 56.8 & 57.2 & 55.3 & 1.35 & 0.6907 \\
\hline Fat depth (mm) & 2.05 & 2.27 & 2.29 & 2.23 & 0.044 & 0.1744 \\
\hline Height at withers $\left(\mathrm{mm} \mathrm{kg}^{-1}\right)$ & 2.81 & 2.71 & 2.69 & 2.71 & 0.061 & 0.5173 \\
\hline Length of back $\left(\mathrm{mm} \mathrm{kg}^{-1}\right)$ & 2.58 & 2.61 & 2.64 & 2.59 & 0.262 & 0.9540 \\
\hline Chest circumference $\left(\mathrm{mm} \mathrm{kg}^{-1}\right)$ & 3.95 & 3.83 & 3.90 & 3.86 & 0.080 & 0.7568 \\
\hline Chest depth $\left(\mathrm{mm} \mathrm{kg}^{-1}\right)$ & 1.44 & 1.41 & 1.40 & 1.42 & 0.030 & 0.7802 \\
\hline Pelvic width $\left(\mathrm{mm} \mathrm{kg}^{-1}\right)$ & 1.07 & 1.04 & 1.05 & 1.04 & 0.019 & 0.5116 \\
\hline \multicolumn{7}{|c|}{ Ultrasound and animal measurements (pre-slaughter measurements): } \\
\hline Muscle depth (mm) & 61.6 & 57.9 & 60.4 & 59.2 & 1.17 & 0.1999 \\
\hline Fat depth $(\mathrm{mm})$ & 2.39 & 2.77 & 2.62 & 2.43 & 0.152 & 0.2077 \\
\hline Height at withers $\left(\mathrm{mm} \mathrm{kg}^{-1}\right)$ & 2.48 & 2.40 & 2.44 & 2.43 & 0.054 & 0.7485 \\
\hline Length of back $\left(\mathrm{mm} \mathrm{kg}^{-1}\right)$ & 2.47 & 2.47 & 2.61 & 2.53 & 0.051 & 0.2415 \\
\hline Chest circumference $\left(\mathrm{mm} \mathrm{kg}^{-1}\right)$ & 3.71 & 2.66 & 3.73 & 3.69 & 0.073 & 0.9397 \\
\hline Chest depth $\left(\mathrm{mm} \mathrm{kg}^{-1}\right)$ & 1.32 & 1.32 & 1.32 & 1.34 & 0.025 & 0.9607 \\
\hline Pelvic width $\left(\mathrm{mm} \mathrm{kg}^{-1}\right)$ & 1.01 & 1.00 & 1.00 & 0.99 & 0.020 & 0.8871 \\
\hline
\end{tabular}

${ }^{1}$ No supplementation at pasture and finished on an ad libitum B $\left(800 \mathrm{~g} \mathrm{~kg}^{-1}\right.$ barley, $140 \mathrm{~g} \mathrm{~kg}^{-1}$ soya bean meal, $40 \mathrm{~g} \mathrm{~kg}^{-1} \mathrm{molasses}$ and $20 \mathrm{~g} \mathrm{~kg}^{-1}$ minerals); ${ }^{2}$ Supplemented with $3 \mathrm{~kg}$ DM per head daily of B at pasture and finished on ad libitum B; ${ }^{3}$ Supplemented with $3 \mathrm{~kg}$ DM per head daily of B at pasture and finished on ad libitum BM $\left(400 \mathrm{~g} \mathrm{~kg}^{-1}\right.$ barley, $400 \mathrm{~g} \mathrm{~kg}^{-1}$ maize meal, $140 \mathrm{~g} \mathrm{~kg}^{-1}$ soya bean meal, $40 \mathrm{~g} \mathrm{~kg}^{-1}$ molasses and $20 \mathrm{~g} \mathrm{~kg}^{-1}$ minerals). ${ }^{4}$ Supplemented with $3 \mathrm{~kg} \mathrm{DM}$ per head daily of BM at pasture and finished on ad libitum BRPF (750 g kg${ }^{-1}$ barley, 140 $\mathrm{g} \mathrm{kg}^{-1}$ soya bean meal, $50 \mathrm{~g} \mathrm{~kg}^{-1}$ megalac ${ }^{\circledast}, 40 \mathrm{~g} \mathrm{~kg}^{-1}$ molasses and $20 \mathrm{~g} \mathrm{~kg}^{-1}$ minerals)'; ${ }^{5}$ Standard error of the mean

Kill-out proportion and carcass conformation score (Table 4) were similar for all treatment groups. Carcass fat score tended ( $p=0.0514$ ) to be greater for T3 than T4 and T1 while T2 was intermediate. On an absolute basis perinephric and retroperitoneal fat tended $(p=0.0526)$ to be greater for both T3 and T4 than T1, while T2 was intermediate. 
B. Murphy et al. (2018) 27: 28-37

When expressed as a proportion of carcass weight perinephric and retroperitoneal fat was greatest for T4 and lowest for T1 with both T2 and T3 intermediate $(p<0.05)$. Ultimate $\mathrm{pH}$ and temperature were similar across all treatment groups.

Table 4. Effects of finishing regime on ultrasound measurements, animal and carcass measurements and ultimate $\mathrm{pH}$ and ultimate temperature of Holstein-Friesian bulls slaughtered at 15 months of age

\begin{tabular}{|c|c|c|c|c|c|c|}
\hline & $\mathrm{T} 1^{1}$ & $\mathrm{~T} 2^{2}$ & $T 3^{3}$ & $\mathrm{~T} 4^{3}$ & SEM $^{5}$ & $p$ value \\
\hline \multicolumn{7}{|l|}{ Carcass performance: } \\
\hline Carcass weight (kg) & 283 & 296 & 288 & 281 & 8.4 & 0.5680 \\
\hline Kill-out proportion $\left(\mathrm{g} \mathrm{kg}^{-1}\right)$ & 518 & 517 & 521 & 509 & 3.5 & 0.1191 \\
\hline Conformation score (1-15) & 5.53 & 5.47 & 5.64 & 5.38 & 0.296 & 0.9504 \\
\hline Fat score (1-15) & $5.33^{\mathrm{a}}$ & $6.13^{\mathrm{ab}}$ & $6.45^{\mathrm{b}}$ & $5.46^{\mathrm{a}}$ & 0.315 & 0.0514 \\
\hline Perinephric and retroperitoneal fat $(\mathrm{kg})$ & $8.58^{\mathrm{a}}$ & $9.82^{\mathrm{ab}}$ & $11.15^{\mathrm{b}}$ & $11.37^{\mathrm{b}}$ & 0.785 & 0.0526 \\
\hline $\begin{array}{l}\text { Perinephric and retroperitoneal fat } \\
\left(\mathrm{g} \mathrm{kg} \mathrm{carcass}^{-1}\right)\end{array}$ & $30.44^{\mathrm{a}}$ & $32.90^{\mathrm{ab}}$ & $38.84^{\mathrm{ab}}$ & $39.92^{\mathrm{b}}$ & 2.275 & $<0.05$ \\
\hline Ultimate $\mathrm{pH}(0-14)$ & 5.67 & 5.66 & 5.74 & 5.68 & 0.052 & 0.7396 \\
\hline Ultimate temperature $\left({ }^{\circ} \mathrm{C}\right)$ & 4.37 & 4.41 & 4.38 & 4.15 & 0.148 & 0.5747 \\
\hline \multicolumn{7}{|l|}{ Carcass measurements $\left(\mathrm{mm} \mathrm{kg} \operatorname{carcass}^{-1}\right)$ : } \\
\hline Carcass length & 4.72 & 4.64 & 4.65 & 4.86 & 0.116 & 0.5237 \\
\hline Carcass depth & 1.62 & 1.61 & 1.63 & 1.76 & 0.050 & 0.1160 \\
\hline Leg length & 2.56 & 2.45 & 2.46 & 2.75 & 0.110 & 0.2137 \\
\hline Leg width & $1.61^{\mathrm{ab}}$ & $1.51^{\mathrm{a}}$ & $1.55^{\mathrm{ab}}$ & $1.65^{\mathrm{b}}$ & 0.039 & 0.0551 \\
\hline Leg thickness & 1.02 & 0.96 & 0.99 & 0.99 & 0.030 & 0.5233 \\
\hline Circumference of round & 4.14 & 4.01 & 4.0 & 4.22 & 0.030 & 0.2781 \\
\hline
\end{tabular}

${ }^{1}$ No supplementation at pasture and finished on an ad libitum B $\left(800 \mathrm{~g} \mathrm{~kg}^{-1}\right.$ barley, $140 \mathrm{~g} \mathrm{~kg}^{-1}$ soya bean meal, $40 \mathrm{~g} \mathrm{~kg}^{-1} \mathrm{molasses}$ and 20 $\mathrm{g} \mathrm{kg}^{-1}$ minerals); ${ }^{2}$ Supplemented with $3 \mathrm{~kg} \mathrm{DM}$ per head daily of B at pasture and finished on ad libitum B; ${ }^{3}$ Supplemented with $3 \mathrm{~kg}$ DM per head daily of $B$ at pasture and finished on ad libitum BM $\left(400 \mathrm{~g} \mathrm{~kg}^{-1}\right.$ barley, $400 \mathrm{~g} \mathrm{~kg}^{-1}$ maize meal, $140 \mathrm{~g} \mathrm{~kg}^{-1}$ soya bean meal, $40 \mathrm{~g} \mathrm{~kg}^{-1}$ molasses and $20 \mathrm{~g} \mathrm{~kg}^{-1}$ minerals); ${ }^{4}$ Supplemented with $3 \mathrm{~kg} \mathrm{DM}$ per head daily of BM at pasture and finished on ad libitum BRPF (750 $\mathrm{g} \mathrm{kg}^{-1}$ barley, $140 \mathrm{~g} \mathrm{~kg}^{-1}$ soya bean meal, $50 \mathrm{~g} \mathrm{~kg}^{-1}$ megalac ${ }^{\oplus}, 40 \mathrm{~g} \mathrm{~kg}^{-1}$ molasses and $20 \mathrm{~g} \mathrm{~kg}^{-1}$ minerals)'; ${ }^{5}$ Standard error of the mean

\section{Ultrasonic, animal and carcass measurements}

Finishing strategy had no effect on subcutaneous fat depth or longissimus dorsi muscle depth (Table 3). Carcass measurements expressed as a proportion of carcass weight; carcass length, carcass depth and leg length were unaffected by treatment. However, leg width scaled to carcass weight tended $(p=0.06)$ to be greater for T4 than $\mathrm{T} 2$, with both T1 and T3 intermediate. Relative to carcass weight, leg thickness and circumference of round were similar across all finishing strategies.

\section{Discussion}

A high level of animal performance is required throughout the animal's lifetime to achieve the minimum carcass weight $(270 \mathrm{~kg}$ ) and fat score (equivalent to 6 in the present study) for dairy bulls slaughtered at 15 months of age. Numerous studies have shown that an ADG of $1.4 \mathrm{~kg}$ can be achieved for dairy and dairy $\times$ beef bulls finished on a concentrate intensive diet (Keane and Fallon 2001, Murphy et al. 2017a and b). However, achieving high levels of animal performance during the grazing season to optimise animal performance during the calfhood stage can prove difficult. Kelly et al. (2013) recommended a minimum live weight of $240 \mathrm{~kg}$ at 35 weeks of age as the necessary target for male dairy calves to be considered for the 15 month bull production system. Achieving the minimum requirement for fat score has also been cited as an issue for young bull beef production (Kirkland et al. 2007, O'Riordan et al. 2012). Therefore, refining blueprints for concentrate supplementation at pasture during the first grazing season and altering the composition of the finishing diet for the 15 month bull production system may improve animal performance and fat score. 


\section{Calf performance}

Although this does ensure that animal performance is optimised, the profitability of the system can be marginal particularly if concentrate price is high. It is well recognised that increasing the proportion of grazed grass in an animal's feed budget reduces the costs of production (Crosson et al. 2009). In dairy calf to beef production systems in Ireland, calves are typically pasture grazed with strategic concentrate supplementation during defined periods; from turnout to early May and mid-September to housing, and moderate levels of performance are achieved (Campion et al. 2009). Murphy et al. (2017b) concluded that male dairy calves offered grazed grass during the calfhood stage and slaughtered at 15 months of age should be either finished on a concentrate intensive diet for greater than 200 days (i.e. reduce the length of the grazing season) or allocated increased levels of concentrate supplementation at pasture before concentrate intensive indoor finishing. The latter proposal could maintain animal performance by counteracting the deterioration in pasture quality in the latter stage of the grazing season. Animal performance of T1 at pasture in the current study was greater than anticipated. This may have been a consequence of the greater than expected herbage quality available as highlighted by the chemical composition; DM digestibility and organic matter digestibility. Consequently live weight at calf housing for T1 was greater than that reported previously by Campion et al. (2009) and Murphy et al. (2017b) where calves were offered $2 \mathrm{~kg}$ DM per day; $210 \mathrm{~kg}$ and $230 \mathrm{~kg}$, respectively. Calves in T4 in the present study had greater ADG at pasture than T1. Murphy et al. (2017b) reported that male dairy calves supplemented with additional levels of concentrates ( 2 $\mathrm{kg}$ DM and $1 \mathrm{~kg}$ DM of concentrate per head daily) throughout the first season at pasture were $17 \mathrm{~kg}$ heavier at calf housing. Subsequent carcass performance from Murphy et al. (2017b) reported that male dairy calves supplemented with greater levels of concentrates tended to have heavier carcasses with greater fat scores than those offered lower levels of concentrate supplementation. The greater carcass weight for calves supplemented at pasture was not observed in the present study. This was largely attributed to the greater ADG of T1 at pasture. In the current study live weight at housing was positively correlated with carcass weight $\left(R^{2}=0.65\right)$.

\section{Finishing phase}

During the finishing phase in the current study, ADG was greater than that previously reported for dairy bulls slaughtered at 15 months of age. Murphy et al. (2017b) reported an ADG of $1.34 \mathrm{~kg}$ for dairy bulls finished on a concentrate ad libitum diet while Keane and Fallon (2001) achieved an ADG of $1.36 \mathrm{~kg}$ for bulls finished over a 10 month period on a concentrate ad libitum diet. Conformation score of HF bulls in the current study was similar to that reported in previous studies (Keane and Fallon 2001, Alberti et al. 2008). This is consistent with the findings of Guerrero et al. (2013), who reported that a finishing period of 145 days removed differences that were influenced by production system pre-finishing. Guerrero et al. (2013) reported no difference in carcass weight, kill-out proportion or conformation score between Gascon bulls managed under intensive and extensive conditions prefinishing. However, differences in fat score were evident. Irrespective of treatment group all finishing strategies achieved the required carcass weight and conformation scores in the present study.

The increased androgen activity of bulls compared to steers resulted in greater muscle but lower fat deposition (Sillence 2004). Consequently, achieving an adequate fat cover for bulls can be difficult particularly when slaughtered at a younger age. Previously Prendiville et al. (2012) reported that fat score increased as age at slaughter increased for dairy bulls slaughtered at 15, 19 and 22 months of age, respectively. However, current UK market specifications dictate that dairy bulls be slaughtered at less the 16 months of age and achieve a fat score of 6 or greater (Dawn Meats 2011). Fat scores achieved in the current study were consistent with that previously reported for dairy bulls finished on high concentrate or concentrate ad libitum diets (Kirkland et al. 2007, Murphy et al. 2017a). The energy density of the finishing diet in the present study increased from 0.96 (UFV) $\mathrm{kg}^{-1}$ (B) to 0.98 UFV kg-1 (BM) to 1.03 UFV kg-1 (BRPF) to evaluate the effects on fat score. The greater UFV value of maize meal (1.06 UFV kg-1) compared to rolled barley (0.99 UFV kg-1; INRA 1989) suggests that maize based rations may have the potential to enhance fat deposition during the finishing period.

Results from the present study showed that carcass fat score and perinephric and retroperitoneal fat were similar for T1 and T2. However, T3 had a 1.12 unit greater carcass fat score and $2.57 \mathrm{~kg}$ more perinephric and retroperitoneal fat than T1. Consistent with the findings of Keane (2008), results from the present study showed no difference in live weight at slaughter, carcass weight or fat score for dairy bulls finished on T2 or T3. Similarly, Lenehan et al. (2015) reported no difference in fat scores for suckler bulls finished on ad libitum barley and maize meal based rations. However, estimated individual concentrate DMI during the finishing period was $196 \mathrm{~kg}$ greater for T2 than T3. This is consistent with the findings of Lenehan et al. (2015), who reported lower concentrate intakes for continental bulls offered $426 \mathrm{~g} \mathrm{~kg}^{-1}$ barley, $426 \mathrm{~g} \mathrm{~kg}^{-1}$ maize meal, $70 \mathrm{~g} \mathrm{~kg}^{-1}$ soya bean meal, $50 \mathrm{~g} \mathrm{~kg}^{-1} \mathrm{molas}^{-}$ ses and $28 \mathrm{~g} \mathrm{~kg}^{-1}$ than bulls offered $862 \mathrm{~g} \mathrm{~kg}^{-1}$ barley, $60 \mathrm{~g} \mathrm{~kg}^{-1}$ soya bean meal, $50 \mathrm{~g} \mathrm{~kg}^{-1}$ molasses and $28 \mathrm{~g} \mathrm{~kg}^{-1}$. 
Interestingly, perinephric and retroperitoneal fat was $2.79 \mathrm{~kg}$ greater for T4 than T1 but carcass fat score was similar for both groups. This highlights differences in the deposition of fat between T1 and T4. Previously Steen (1995) reported that Friesian cattle exhibited greater deposition of internal fat than Limousin $\times$ Friesian and Belgian Blue $\times$ Friesian which would have made a major contribution to the lower efficiency of carcass and lean gains. This could explain the similar carcass performance of the treatment groups in the current study. De Smet et al. (2000) demonstrated that increasing the energy density of the finishing ration for beef bulls, through beef tallow supplementation, resulted in greater carcass fat scores while Gillis et al. (2004) and Sutter et al. (2000) reported no difference in fat score for beef heifers and dairy bulls finished with or without RPF supplementation, respectively.

Variation was apparent within each of the finishing strategies for carcass performance. Although supplementing concentrates at pasture ( $\mathrm{T} 2, \mathrm{~T} 3$ and $\mathrm{T} 4)$ did increase the proportion of bulls that achieved the required carcass fat score compared those unsupplemented at pasture (T1), variation within treatment was also apparent. The proportion of bulls that achieved the target fat score was $0.33,0.73,0.82$ and 0.50 for $\mathrm{T} 1, \mathrm{~T} 2, \mathrm{~T} 3$ and $\mathrm{T} 4$, respectively. Similarly, the proportion of bulls that achieved target carcass weight for T1, T2, T3 and T4 were $0.73,0.87,0.82$ and 0.64 , respectively while the proportion of bulls that attained the target conformation score was $0.80,0.80$, 0.91 and 0.79 for T1, T2, T3 and T4, respectively. However, combining these performance parameters to present the proportion of bulls that achieved the current UK market specifications (Dawn Meats 2011) highlighted that $0.27,0.53,0.55$ and 0.43 for T1, T2, T3 and T4, respectively, achieved performance targets. This highlights the difficulty in achieving the required carcass weight and carcass conformation and fat scores for dairy bulls slaughtered at 15 months even when lifetime ADG was in excess of $1.15 \mathrm{~kg}$ for all treatment groups.

\section{Conclusion}

The results of this study indicated that there is a role for pasture in the production of 15 month dairy bull beef. However, excellent grassland management is central to the successful integration of grazed grass in the 15 month bull production system. Across all finishing strategies a live weight at housing of approximately $250 \mathrm{~kg}$ or greater was achieved. Despite all treatments realising the required age at slaughter, carcass weight and conformation score specifications, only T2 and T3 achieved the required fat score. No difference in animal performance or feed efficiency was observed between T2 and T3. However despite high levels of animal performance of T1 and T4, a large proportion of carcasses did not achieve the required market specifications (Dawn Meats 2011). Thus the recommended blueprint of production to achieve the current UK market specifications requires dairy bulls be supplemented with $3 \mathrm{~kg}$ DM of a barley based concentrate per head daily at pasture from mid-August to housing followed by indoor finishing on an ad libitum B or BM based rations for 200 days.

\section{Acknowledgements}

The authors wish to acknowledge the diligent work of Brendan Swan and the farm staff in Teagasc Johnstown Castle Research centre. This project (11/SF/322, "BullBeef") was funded by the Irish Department of Agriculture, Food and the Marine's competitive research programmes.

\section{References}

Alberti, P., Panea, B., Saudo, C., Olleta, J.L., Ripoll, G., Ertbjerg, P., Christensen, M., Gigli, S., Failla, S., Concetti, S., Hocquette, J.F., Jailler, R., Rudel, S., Renand, G., Nute, G.R., Richardson, R.I. \& Williams, J.L. 2008. Live weight, body size and carcass characteristics of young bulls of fifteen European breeds. Livestock Science 114: 19-30. https://doi.org/10.1016/j.livsci.2007.04.010

Ashfield, A., Wallace, M., McGee, M. \& Crosson, P. 2014. Bioeconomic modelling of compensatory growth for grass-based dairy calf-to-beef production systems. Journal of Agricultural Science 152: 805-816. https://doi.org/10.1017/\$0021859613000531

Bown, M.D., Muir, P.D. \& Thomson, B.C. 2016. Dairy and beef breed effects on beef yield, beef quality and profitability: a review. New Zealand Journal of Agriculture Research 59: 1-11. https://doi.org/10.1080/00288233.2016.1144621

Campion, B., Keane, M.G., Kenny, D.A. \& Berry, D.P. 2009. Evaluation of estimated genetic merit for carcass weight in beef cattle: live weights, feed intake, body measurements, skeletal and muscular scores, and carcass characteristics. Livestock Science 126: 87-99. https://doi.org/10.1016/j.livsci.2009.06.004

Crosson, P., McGee, M. \& Drennan, M.J. 2009. The economic impact of turnout date to pasture in spring of yearling cattle on suckler beef farms. In: Agricultural Research Forum. Tullamore, Ireland. p. 77.

Dawn Meats 2011. Dawn Direct September Issue. Waterford, Ireland. Dawn Meats Press: p. 1-5. http://source-www.dawnmeats. com/index.php/downloads/finish/10-dawn-direct-ireland/6-dawndirect-september-2011 
B. Murphy et al. (2018) 27: 28-37

De Boer, H., Dumont, B.L., Pomeroy, R.W. \& Weniger, J.H. 1974. Manual on EAAP reference methods for the assessment of carcass characteristics in cattle. Livestock Production Science 1: 151-164. https://doi.org/10.1016/0301-6226(74)90055-4

De Smet, S., Webb, E.C., Claeys, E., Uytterhaegen, L. \& Demeyer, D.I. 2000. Effect of dietary energy and protein levels on fatty acid composition of intramuscular fat in double-muscled Belgian Blue bulls. Meat Science 56: 73-79. https://doi.org/10.1016/ S0309-1740(00)00023-1

EC 2006. Council Regulations (EC) No 1183/2006 of 24 July 2006 concerning the community scale of the classification of carcasses of adult bovine animals. http://eur-lex.europa.eu/eli/reg/2006/1183/oj. Accessed 20 January 2017.

Fallon, R.J. 1992. Calf Rearing. Teagasc Sandymount Avenue, Ballsbridge, Dublin 4, Ireland. 56 p.

Gillis, M.H., Duckett, S.K., Sackmann, J.R., Realini, C.E., Keisler, D.H. \& Pringle, T.D. 2004. Effects of supplemental rumen-protected conjugated linoleic acid or linoleic acid on feedlot performance, carcass quality, and leptin concentrations in beef cattle. Journal of Animal Science 82: 851-859. https://doi.org/10.2527/2004.823851x

Grundy, H.F., Hardy, R., Chapple, D.G. \& Davies, M.H. 2000. Performance of late maturing beef $x$ dairy cattle finished on grass silage plus concentrate or all-concentrate diets. Irish Journal of Agricultural and Food Research 39: 409-417.

Guerrero, A., Saudo, C., Albertí, P., Ripoll, G., Campo, M.M., Olleta, J.L., Panea, B., Khliji, S. \& Santolaria, P. 2013. Effect of production system before the finishing period on carcass, meat and fat qualities of beef. Animal 7: 2063-2072. https://doi.org/10.1017/ S1751731113001729

INRA 1989. Ruminant Nutrition: In: Jarrige R. (ed.). Recommended allowances and feed tables. INRA, Paris, France. p. 389.

Keane, M.G. \& Allen, P. 1998. Effects of production system intensity on performance, carcass composition and meat quality of beef cattle. Livestock Production Science 56: 203-214. https://doi.org/10.1016/S0301-6226(98)00155-9

Keane, M.G. \& Fallon, R.J. 2001. Effects of feeding level and duration on finishing performance and slaughter traits of HolsteinFriesian young bulls. Irish Journal of Agricultural and Food Research 40: 145-160.

Keane, M.G. 2008. Comparison of barley and barley/maize based finishing diets for young bulls. In: Agricultural Research Forum. Tullamore, Ireland. p. 88.

Kelly, A.K., Carty D. \& Tuffy N. 2013. Lessons learned from the dairy calf to beef programme. Profitable beef from the dairy herd. In: Teagasc National Beef Conference. Kilkenny, Ireland: p. 33-37.

Kirkland, R.M., Patterson, D.C., Keady, T.W.J., Moss, B.W. \& Steen, R.W.J. 2007. Beef production potential of Norwegian Red and Holstein-Friesian bulls slaughtered at two ages. Animal 1: 1506-1514. https://doi.org/10.1017/S1751731107000791

Ladeira, M.M., Schoonmaker, J.P., Gionbelli, M.P., Dias, J.C., Gionbelli, T.R., Carvalho, J.R.R. \& Teixeira, P.D. 2016. Nutrigenomics and Beef Quality: A Review about Lipogenesis. International Journal of Molecular Sciences 17: 918-939. https://doi.org/10.3390/ ijms17060918

Lenehan, C., Moloney, A.P., O'Riordan, E.G., Kelly, A.K. \& McGee, M. 2015. Effects of substituting barley with maize on the performance of suckler bred bulls offered a high concentrate diet. In: Agricultural Research Forum. Tullamore, Ireland. p. 82.

McGee, M., Keane, M.G., Neilan, R., Moloney, A.P. \& Caffrey, P.J. 2005. Production and carcass traits of high dairy genetic merit Holstein, standard dairy genetic merit Friesian and Charolais $\times$ Holstein-Friesian male cattle. Irish Journal of Agricultural and Food Research 44: 215-231.

Meat Promotion Wales 2014. Introduction to beef finishing systems. Options for beef farms in Wales. www.hccmpw.org.uk. Accessed 28 February 2017.

More O'Ferrall, G.J. \& Keane, M.G. 1989. A comparison for live weight and carcass production of Charolais, Hereford and Friesian steer progeny from Friesian cows finished on two energy levels and serially slaughtered. Animal Production 50: 19-28. https:// doi.org/10.1017/S0003356100004438

Muir, P.D., Smith, N.B., Wallace, G.J., Cruickshank, G.J. \& Smith, D.R. 1998. The effect of short-term grain feeding on liveweight gain and beef quality. New Zealand Journal of Agricultural Research 41: 517-526. https://doi.org/10.1080/00288233.1998.9513334

Murphy, B., Crosson, P., Kelly A.K. \& Prendiville R. 2017a. An economic and greenhouse gas emissions evaluation of pasture-based dairy calf-to-beef production systems. Agricultural Systems 154: 124-132. https://doi.org/10.1016/j.agsy.2017.03.007

Murphy B., Crosson, P., Kelly A.K. \& Prendiville R. 2017b. Animal performance and economic implications of alternative production systems for dairy bulls slaughtered at 15 months of age. Irish Journal of Agricultural and Food Research 53: 90-103. https:// doi.org/10.1515/ijafr-2017-0010

Nogalski, Z., Wielgosz-Groth, Z., Purwin, C., Sobczuk-Szul, M., Mochol, M., Pogorzelska-Przybytek, P. \& Winarski, R. 2014. Effect of slaughter weight on the carcass value of young crossbred (Polish Holstein-Friesian $\times$ Limousin) steers and bulls. Chilean Journal of Agricultural Research 74: 59-66. https://doi.org/10.4067/S0718-58392014000100010

Nürnberg, K., Wegner, J. \& Ender, K. 1998. Factors influencing fat composition in muscle and adipose tissue of farm animals. Livestock Production Science 56: 145-156. https://doi.org/10.1016/S0301-6226(98)00188-2

O'Riordan, E.G., McGee, M., Moloney, A.P. \& Crosson, P. 2012. Bulls from the beef cow herd: effect of system of production on growth and carcass characteristics. In: Agricultural Research Forum. Tullamore, Ireland. p. 52.

O'Donovan, M., Connolly, J., Dillon, P., Rath, M. \& Stakelum, G. 2002. Visual assessment of herbage mass. Irish Journal of Agricultural and Food Research 41: 201-211.

O’Donovan, M., Lewis, E. \& O'Kiely, P. 2011. Requirements of future grass-based ruminant production systems in Ireland. Irish Journal of Agricultural and Food Research 50: 1-21.

Owens, D., McGee, M., Boland, T. \& O'Kiely, P. 2008. Intake, rumen fermentation and nutrient flow to the omasum in beef cattle fed grass silage fortified with sucrose and/or supplemented with concentrate. Animal Feed Science and Technology 144: 23-43. https://doi.org/10.1016/j.anifeedsci.2007.09.032 
O'Mara, F. 2000. A Net Energy System for Cattle and Sheep. Version 1.2. National University of Ireland, Dublin, Ireland.

Pettigrew, E.J., Morris, S.T., Back, P.J., Kenyon, P.R., Berry, J., Donald, A.J., Lane, A.L. \& Hickson, R.E. 2017. Growth of weaned Friesian bull calves on a herb sward or with concentrate supplementation during late summer and early autumn. New Zealand Journal of Agricultural Research 60: 70-79. https://doi.org/10.1080/00288233.2016.1259641

Prendiville, R., French, P. \& O'Riordan E.G. 2012. Effects of production system and the influence of concentrate supplementation during the first season at pasture for dairy bred bulls. In: Agricultural Research Forum. Tullamore, Ireland. $51 \mathrm{p}$.

Schneider, C.A., Rasband, W.S. \& Eliceiri, K.W. 2012. NIH Image to ImageJ: 25 years of image analysis. Nature Methods 9: 671-675. https://doi.org/10.1038/nmeth.2089

Schoonmaker, J.P., Cecava, M.J., Fluharty, F.L., Zerby, H.N. and Loerch, S.C. 2004. Effect of source and amount of energy and rate of growth in the growing phase on performance and carcass characteristics of early-and normal-weaned steers. Journal of Animal Science 82: 273-282. https://doi.org/10.2527/2004.821273x

Sillence, M.N. 2004. Technologies for the control of fat and lean deposition in livestock. The Veterinary Journal 167: 242-257. https://doi.org/10.1016/j.tvjl.2003.10.020

Steen, R.W.J. 1995. The effect of plane of nutrition and slaughter weight on growth and food efficiency in bulls, steers and heifers of three breed crosses. Livestock Production Science 42: 1-11. https://doi.org/10.1016/0301-6226(95)00002-3

Sutter, F., Casutt, M.M., Ossowski, D.A., Scheeder, M.R.L. \& Kreuzer, M. 2000. Comparative evaluation of rumen-protected fat, coconut oil and various oilseeds supplemented to fattening bulls: 1 . Effects on growth, carcass and meat quality. Archives of Animal Nutrition 53: 1-23. https://doi.org/10.1080/17450390009381935 